\title{
MINORITY LANGUAGES IN ESTONIAN SEGREGATIVE LANGUAGE ENVIRONMENTS
}

\author{
Elvira Küün \\ Tallinn University and University of Vilnius
}

\begin{abstract}
The goal of this project in Estonia was to determine what languages are spoken by students from the 2 nd to the 5 th year of basic school at their homes in Tallinn, the capital of Estonia. At the same time, this problem was also studied in other segregated regions of Estonia: Kohtla-Järve and Maardu. According to the database of the population census from the year 2000 (Estonian Statistics Executive Office?s census 2000), there are representatives of 142 ethnic groups living in Estonia, speaking a total of 109 native languages. At the same time, the database doesn't state which languages are spoken at homes. The material presented in this article belongs to the research topic "Home Language of Basic School Students in Tallinn" from years 2007-2008, specifically financed and ordered by the Estonian Ministry of Education and Research (grant No. ETF 7065) in the framework of an international study called "Multilingual Project". It was determined what language is dominating in everyday use, what are the factors for choosing the language for communication, what are the preferred languages and language skills. This study reflects the actual trends of the language situation in these cities.
\end{abstract}

Keywords: language domination, viability of language, language skills, language repertoire, language selection, minority languages

\section{Introduction}

Almost all languages spoken by 1,000 people or less are endangered, although even languages spoken much more widely are susceptible to the same pressure. Among these small languages, many have experienced the stage of near extinction, because only the remaining elderly people are still speaking those languages (Crystal 2000). These languages have not been passed along to the younger generation for a long time and thus as the older generation will die out in time, these languages will not be spoken any more. Together with losing languages, much knowledge, many beliefs 
and values also become lost that were kept by the community, or they at least diminish in time: they will be more and more replaced by the knowledge and values of the dominating language and culture (Edwards 2002).

Language can vanish very quickly if it is forbidden by law from being used in schools and if the language transfer mechanism at home is not working anymore. Re-valuing language via school is a very slow process. A decrease of language use can take just a couple of decades, but it will take much more time before the same language starts to be reborn again from seeds, and the spreading of such language will take even longer (Baker 2006).

The rebirth of a language in education starts not from small students, but instead needs a priori the specific training and availability of teachers, because it is in their power to revitalise a minority language via the education system. Thus, teachers need to cooperate with parents, language activists and language planners in order to save a language. Kenneth Hyltenstam and Christopher Stroud (1996) add that when analysing language shift, the individual and personal level is also very important for preserving a language, besides the social dimension and the dimension of the community of language speakers.

\section{The linguistic identity of linguistic minorities}

A child's mother tongue has a strong impact on the child's choice of language, while the father tongue has not been found to have such a great role (Bayley and Schecter 2003: 18), yet mother tongue does not necessarily coincide with the home language (Baker and Jones 1998). The term "home language" has been preferred by some linguists to refer to characteristic dialects and languages often used solely in the home context, and these languages may in many cases be transferable to succeeding generation only in oral form (Moon et al. 2000: 775).

On the other hand, linguistic minorities can be defined as individuals in whose homes occurs active use of a language other than the one used by the majority in the society and who thus have the opportunity to raise the level of their linguistic proficiency in the language that is socially in widest use (Goldenberg et al. 2006: 21). The term dominant language is used to refer to a language of which the speaker has the best knowledge or which he or she uses 
the most (Baker and Jones 1998). Language proficiency is the ability of an individual to create and understand language (proficiency is usually assessed by evaluating the proficiency level in four component linguistic skills) (Baker 2006).

As language is one of the most marked individual characteristics, language consequently represents and mediates a determining element of human identity (Hoffmann and Ytsma 2004). Linguistic identity - the linguonym - makes up one of the most important parts of a person's social identity (Skutnabb-Kangas 2000). Linguistic identity is self-identification with some definite language (Iskanius 2005). The linguistic identity of minority groups has been viewed as the adoption of an unofficial language as a mother tongue or home language (Li 2001: 137).

The labour market is one of the strongest factors impacting linguistic changes and views; it also impacts linguistic choices, and linguistic identity as well (McAdams 1997). A number of other factors impel people either to switch or retain a minority language. For example, ethnic groups that emphasize family ties appear to have a strong effect on their children's views when it comes to learning and using their own ethnic language at home (Gans 1997). Their family as a group of people has remained an important institution in the attempt to retain languages (Schwartz 2008: 400). However, the relationship between the choice of language and identity is very significant. In choosing a language, people are standing face-to-face with a choice of identity or community (Mills 2001: 400).

\section{Informal language planning}

The maintenance of home language development would result in a failure to, among other consequences of a cultural loss, which also reduces the extent of contact with family members (Anderson 2004). Moreover, they are a threat to children who have not received prior to the second language learning opportunities to adequately develop the first language of their own cognitive skills, academic skills and abilities than the later development of their peers who have had the opportunity to develop and use their first language (Cummins 1984). The language of instruction or the retention agents include one more important: the opportunity to speak this language (Kohnert et al. 2005). 
An alternative perspective of maintaining the home language is language, in which parents use their children active in their dealings with the minority (Goldenberg et al. 2006). One reason for this could be that the parents to interact with their children in the language, what they do best, that is, in order to ensure the best possible linguistic model, and so to say, linguistic input for children. It is observed that the skills acquired in one language, and knowledge exchange in the second language, while at the same time contributes to maintaining the home language of the family and community members, using the language skills and literacy in general, including, in particular, it facilitates the acquisition of a second language (L2) (Wong Fillmore 1991). Another reason to maintain the first language at home is the importance of cultural, cognitive and pragmatic reasons (Goldenberg et al. 2006: 303). However, there is no clear answer to the question of language at home should seek to encourage children's literacy development. Some studies provide further positive associations at home and use a second language, second language literacy achievement (see Monzó and Rueda 2001).

I. Piller (2002: 62) refers to unofficial language planning, although he has observed that many married couples have never adopted an informed decision regarding the language to be used at their respective homes; therefore, the choice of language is accidental. Also, there are those who consciously keep two languages apart in the case of different situations and define specific strategies, identifying the languages to be talked to both each other and to their children. Unfortunately, however, the home language level of the minority language-speaking children, with of threat to the social, emotional and cultural links is in jeopardy. This is especially real when the language, a language spoken at home, is not widely used in education or in the community (Anderson 2004).

\section{Importance of domestic language studies within Estonian context}

For Estonia as a European Union Member State it's important to identify which is the current realistic language situation and which are the languages, used by Estonian population - this is required by the European Union language policies which promote multilingualism (Commission of the European Communities 2005). 
It is as important to determine the realistic scope of use of languages and variety of languages, used within the public and private sphere. Based on the European Convention (2003), the European Union must accept any cultural, religious and linguistic differences (Baldauf and Kaplan 2006).

Based on the results of a census of 2000 (Estonian Statistics Executive Office's census 2000), the representatives of 142 ethnic groups are residing in Estonia, speaking, in total, in 109 native languages. Such registered information indicates which languages are assumed to be native languages. However, it's not quite clear which languages and language combinations are used in domestic environment.

Domestic language studies give a feedback on educational policies, contributing to more efficient organisation of domestic language studies. It can be also linked to the right for a native language, defined as a part of linguistic human rights sphere. It is important to be aware of the fact that attaching value to our own language and culture provides better pre-requisites for developing a positive attitude towards both ourselves and the destination language and culture.

The studies underlying this publication are based on the research of home language of students of Tallinn basic schools (and other segragative environments in Estonia). The research, commissioned by Estonian Ministry of Education and Research (ETF grant 7065), who has also been the provider of targeted financing of the research project, was carried out in 2007-2008 in the framework of an international study "Multilingual Cities Project", the aim of which was to gather, analyse, and compare home language data on basic school students in Tallinn, Riga and Vilnius, the three Baltic capitals in order to compare the outcome with the results derived from the reports on minority language studies conducted among basic school students in some other cities of Europe (Extra and Yagmur 2004). The characteristic feature of each of the towns is its multilanguage and multicultural population, the development of which can well be predicted by measuring the variability and loyalty of the language of basic school students. 


\section{The development of segregative language environment: Maardu}

Maardu with its population of about 16000 is considered to belong to ten largest towns in Estonia. After the Second World War the phosphorite mining and processing in Maardu continued to develop. Like in Kohtla-Järve it considerably increased the nonEstonian immigration. It is hardly possible to find a city in Estonia, which like Maardu has the population consisting of such a variety of representatives of different nationalities. The population consists predominantly of Russians; approximately $10 \%$ are Estonians. There live representatives of 41 different nationalities belonging to different confessions in the Maardu City (Official homepage of Maardu city 2009).

\section{Purposes of the study}

The goal of the study was to determine the language and education needs of students. The final goal is to put these data into the multilingual and international perspective.

One of the goals of the project was also to predict the perspectives of languages remaining viable and ethnic identities being preserved. Language has an important role in assessing original linguistic and cultural values, especially if the language being used is not the native language (Iskanius 2005).

The protection of minority languages is very important already in principle, because this relates to one of the human rights in the field of language - the right of own native language. For example, there are 21 Sunday schools for minorities active in Estonia, teaching children their native languages, telling them about the culture and traditions of their origin country (Muldma 2009: 11). But even with all this there is still a risk of a language declining or even vanishing. The reasons for this are often cultural pressure and decline of the prestige of the language in the eyes of the people speaking it. The number of people speaking the language is not always the most important factor - attitude is what counts (Rannut et al. 2003). 


\section{Study methods}

Questionnaires and interviews were used as the study methods, whereas interviews were intended for further specifying some information. The questionnaire was prepared on the basis of experience gathered from studies in other countries. The study is based on questions with multiple answers and the results can be compared both within a country and internationally. This database can be used for predicting the viability and preserving of the language across generations, separately for every language group.

\section{Results}

In Maardu, the home language study involved the students in the 2 nd to the 5 th year of basic school attending Maardu Upper Secondary School, and their parents. The study methods used were as follows: first, a questionnaire to the students and their parents, in order to select the students in that school speaking a minority home language; the second stage used spoken interviews of those students speaking a minority language (a couple of children were interviewed), in order to achieve a deeper understanding about the background of the choice of language of these students and to determine more comprehensively the need to teach those languages in Estonian speaking schools. The same questionnaire was used for students in Maardu as in the above described studies in Kohtla-Järve and Tallinn. The questionnaire for the parents was different. The respondents of the study were considered those students and their parents who have a minority language as their home language or who are of some other ethnic origin than Estonian or Russian. The parents also responded to questions about their spouses/partners and their own parents and parents of their spouses/partners.

A total of 177 students responded to the questionnaire; of these, 9 children had a home language of Russian and a second home language of something else than Estonian. 152 parents responded to the questionnaire (133 mothers and 19 fathers). 


\section{Origin countries}

Analysis of the questionnaire responses showed that the students and their parents have 11 origin countries. Most of them were born in Estonia: these were $96.6 \%$ of the respondent students (i.e. 171 students), $64.9 \%$ of the fathers (115 fathers) and $60.5 \%$ of the mothers (107 mothers). Thus, majority of the students are second generation immigrants.

Table 1 shows the birth countries of the students and their parents.

Table 1. Birth countries of the students and their parents.

\begin{tabular}{|c|c|c|c|c|c|c|}
\hline Born in & Students & & Fathers & & Mothers & \\
\hline & Number & $\%$ & Number & $\%$ & Number & $\%$ \\
\hline Estonia & 171 & 96.6 & 107 & 60.5 & 115 & 64.9 \\
\hline Russia & 2 & 1.1 & 46 & 25.9 & 41 & 23.1 \\
\hline Ukraine & 4 & 2.3 & 12 & 6.8 & 11 & 6.2 \\
\hline Belarus & & & 3 & 1.7 & 3 & 1.7 \\
\hline Lithuania & & & 1 & 0.6 & 1 & 0.6 \\
\hline Latvia & & & 5 & 2.8 & & \\
\hline Kazakhstan & & & & & 4 & 2.3 \\
\hline Armenia & & & & & 1 & 0.6 \\
\hline Hungary & & & & & 1 & 0.6 \\
\hline Kirgizstan & & & 2 & 1.1 & & \\
\hline Azerbaijan & & & 1 & 0.6 & & \\
\hline
\end{tabular}

The next section shows the relations between the home languages of the students and the birth countries of their parents.

\section{Languages used as a home language}

In case of this group it was determined that, similar to the Kohtla-Järve students attending Russian schools (see Küün 2008), the students in the 2nd to the 5th year of basic school attending Maardu Upper Secondary School are dominantly using Russian as their home language, i.e. $91.5 \%$ of the respondent students responded and $8.5 \%$ of the students have home languages of Russian and some other language. 
Table 2. Home languages of the students attending Maardu Upper Secondary School.

\begin{tabular}{|c|c|c|c|}
\hline Language & Number & students & Comments \\
\hline & Number & $\%$ & \\
\hline Estonian & 6 & 3.4 & $\begin{array}{l}3 \text { mothers Estonians, } 3 \text { fathers } \\
\text { Estonians }\end{array}$ \\
\hline Russian & 162 & 91.5 & $\begin{array}{l}\text { Russians, Byelorussians, Ukrainians, } \\
\text { etc. }\end{array}$ \\
\hline Ukrainian & 7 & 3.9 & $\begin{array}{l}6 \text { mothers Ukrainian, } 1 \text { father } \\
\text { Ukrainian }\end{array}$ \\
\hline Lithuanian & 1 & 0.6 & Mother Lithuanian \\
\hline Tatar & 1 & 0.6 & Both parents Tatars \\
\hline
\end{tabular}

In mixed families it is usual that Russian is used as the home language (Rannut, Ü., and Rannut, M. 2007). As shown in table 2, second home languages are the Ukrainian, Lithuanian, Tatar and Estonian languages. The Estonian language was used as a second home language by students having one Estonian parent and one Russian parent; in one family both parents were from an EstonianRussian mixed family.

Also, Estonian is used when speaking to parents and grandparents having Estonian background (a mixture of Estonian and Russian languages) but Russian is preferred when talking to siblings because, as the responses show, the students know this language better. These responses are typical of children in a Russian speaking environment. The responses of the parents show that they, too, have attended Russian speaking schools and some of them were born in Russia.

The second largest group after the Russian speaking students are the Ukrainian speaking students. 3.9\% of students (7 students) considered Ukrainian to be their second home language; of these, six students had a Ukrainian mother and one had a Ukrainian father. 9 mothers and 1 father spoke Ukrainian. 23 parents were born in Ukraine, thus $43.5 \%$ of the parents having born in Ukraine spoke the Ukrainian language, although as a second language, the main language still being Russian. This means that loss of language has happened even among first generation immigrants. Three mothers were speaking to their parents in Ukrainian, but the home language was still Russian and they spoke to their children only in Russian. This shows that the usual language used in Ukrainian families is Russian, especially in mixed families where one parent is Ukrainian. 
When comparing the language use across generations it can be seen that the use of the Ukrainian language is diminishing with each generation. Some parents (3 mothers) were speaking in the Ukrainian language with their parents when they were children, but they attended a Russian speaking school and they are currently speaking with their children only in the Russian language. A large share of the respondent parents born in Ukraine is communicating with their parents in the Russian language as well (3 mothers and 10 fathers). This shows that language loss has happened already in an earlier generation. Possibly learning groups or classes are needed for supporting the Ukrainian language, in order to stop this language from merging into Russian.

To the question: "If there was a school or a class near you with education work in your native language, would you put your children into such school or class?" were parents answered negatively. To the question: "If there were a group for learning the Ukrainian language near you or if such a learning group opened in your school, would you put your child in such a group?" was replied to by one parent that there would be no point in this because the Ukrainian culture is not significantly different from the Russian culture, so the child will get the necessary cultural and linguistic knowledge from a Russian speaking school as well. The rest of the parents had the opposite opinion - they said that it would be a good idea to open such a learning group. This means there are also those who want their children to know the language and culture of their ancestors. Thus, learning groups or classes for the Ukrainian language would probably be needed if there are enough students interested in learning it.

Besides the Ukrainian language, the Lithuanian and the Tatar languages were used as second home languages (in one case it was Lithuanian and in one case Tatar). In case of the Lithuanian language, the mother was a Lithuanian and the father was a Russian. The Russian language was used as the home language and Lithuanian was used as the second language. One parent (mother) of a student stated her place of birth in the questionnaire as Kaunas, Lithuania. There she had attended a Russian speaking school and both Russian and Lithuanian had been used as her home languages. She was speaking in Lithuanian with her parents and was trying to teach Lithuanian to her children as well.

The child of that mother was born in Tallinn. The child speaks Russian and Lithuanian at home (always Russian with the 
father), sometimes in Russian and sometimes in Lithuanian with the mother and the sister. The child speaks in Lithuanian and less frequently in Russian with the grandparents from the mother's side. The language used when communicating with the parents of the father is Russian because they are Russians and don't know the Lithuanian language. Outside home was by respondents used only Russian language.

\section{Home language skills}

In the following, we review the language skills regarding home language as Ukrainian, Lithuanian and Tatar, on a scale of understanding - speaking - reading - writing. All 7 students were able to understand Ukrainian and make themselves understood in speech, but they could only read and write a little in this language. In case of the Lithuanian and Tatar language, the relevant students understood it and were able to speak it, but not read and write in it.

Thus, the spoken skills (understanding and speaking) of these students regarding their home language are better than written skills (reading, writing). The reason for this is that the home languages are used in a spoken manner at home and not taught in school. The reading and writing skills are mainly dependent on whether the relevant language is taught in school; it is also important how much these languages are valued at home. Literacy is very important for preserving a language, thus support groups could be established for learning certain languages, as these would help the children to acquire the skills of reading and writing in these languages.

\section{Comparison of home languages of students from Kohtla-Järve, Maardu and Tallinn}

The students in the 2nd to the 5th year of basic school, involved in the study from schools of Kohtla-Järve (included 1002 respondents), are from two countries and their parents are from 16 countries. Majority of them were born in Estonia: as much as $99.5 \%$ of the students were born here, $82.63 \%$ of mothers and $81.53 \%$ fathers were born in Estonia as well. Thus, most of the students in this group are second generation immigrants already. 5 of the students in this group were born in Russia, 130 mothers (12.97\%) 
and 132 fathers $(13.17 \%)$ were born there as well. The students involved in the study from Maardu Upper Secondary School and also their parents are from 11 countries. Most of the respondents were born in Estonia: $96.6 \%$ of the students, $64.9 \%$ of the fathers and $60.5 \%$ of the mothers. Thus, most of the students in this group, like in the Kohtla-Järve group, are second generation immigrants. When comparing the data from a similar home language study involving students in Tallinn (see Rannut, $\ddot{U}$. and Rannut, M. 2007), it can be seen that the students in Tallinn are from many more different countries - 28 in total - and their parents are from 52 countries. $97 \%$ of the students, $83 \%$ of the mothers and $81 \%$ of the fathers were born in Estonia. Tallinn is the largest city in Estonia and also the city with the most languages; also, the number of respondents in Tallinn is higher. At the same time, the labour market in Tallinn is wider, attracting foreigners into Tallinn, with home languages differing from the local language.

Similar to the students attending Russian speaking schools in Kohtla-Järve, the dominant home language of the students in the 2nd to the 5th year of basic school, attending Maardu Upper Secondary School, is Russian - this is so for $91.5 \%$ of the respondent students; $8.5 \%$ of the students have a second home language as something else than Russian. Such second languages were Ukrainian, Lithuanian, Tatar and Estonian, but the main language was still Russian. $3.9 \%$ of the students considered Ukrainian to be their second home language. 9 mothers and 1 father used Ukrainian as their home language, but as a second language, while the main language was still Russian. When comparing the home language data of the students from the schools of Kohtla-Järve and Maardu to the home language data of the Tallinn students of the same age, it was found that the latter considered a total of as much as 22 languages to be their home languages; according to the data of the Statistical Office, this is $20 \%$ of the total number of languages spoken in Estonia. 2\% of the respondent students from Tallinn consider other languages to be their home languages: Ukrainian, Azerbaijan, English, Byelorussian, Finnish, Italian, Spanish, French, Romanian, Turkish, Bashkir, Georgian, Hebrew, Korean, Hungarian, Arabic, Chinese, Croatian, Portuguese and sign language. Still, the majority of people in Tallinn are using Estonian and Russian as their home languages.

In case of students from Tallinn, English was stated as a home language as well. There were no such cases from Kohtla- 
Järve or Maardu, although the father of one of the students there was from Denmark, three fathers had ethnic roots in Finland and one in Italy. Still, English was not used much as a single home language in Tallinn, either (3 students), but a parallel pair of English and some other language as home languages was more common. English was used as a home language if the parents were from different countries. Usually, English was used at home if neither of the parents was born in Estonia, but there were also cases of both parents being from Estonia but still using English as a home language. The reason for this is the high status of the English language in the world - the parents wish their child to learn this language. For the most part, the use of English as a home language was not related to the origins of the children or to the native languages of the parents.

In Tallinn, only $7 \%$ of the parents from Ukraine used Ukrainian at home; the rest of them used Russian as their home language. Similar to Kohtla-Järve and Maardu, this shows a marked loss of language and a strong relation with mixed marriages. In case of families from Azerbaijan having come to live in Tallinn, 30 parents of the total 43 were using the Azerbaijan language when communicating with the child at home (in 10\% of the families as the first language and in $17 \%$ of the families as the second language); this is a rather large share, especially taking into account the fact that according to the data of the Statistical Office (2000) the Azerbaijan people don't have nearly as large a community in Estonia as do Ukrainians. Regardless of this, the Azerbaijan people have preserved their language markedly better than the Ukrainians. One of the reasons for this can be the trend of foreign immigrants to come to live mainly in the capital city; for example, immigrants from Denmark, Sweden and several other countries are living in Tallinn besides the Azerbaijan people. Usually, recent immigrants value their language more. Still, like in Kohtla-Järve and Maardu, the dominant home language in Tallinn is Russian, used by $61 \%$ of the students in mixed families as the first home language and by $27 \%$ of the students as a second home language (Rannut, Ü. and Rannut, M. 2007).

The students attending Russian speaking schools in KohtlaJärve were using only Russian when communicating with their grandparents. 146 students attending Estonian speaking schools used Estonian when communicating with the grandparents from the mother's side, 66 students were using Russian and 16 students 
were using both Estonian and Russian with them. 150 students were using the Estonian language with the grandparents from the father's side, 60 students were using Russian and 18 students were using both Estonian and Russian for this. Estonian was the communication language if the grandparents were Estonians. The respondent students from Maardu also spoke Russian with their grandparents. The students having grandparents with Estonian background spoke a mixed language of Estonian and Russian with them. One of the respondent students from Maardu also used the Lithuanian language when communicating with the grandparents and one student used the Tatar language for this. When comparing language use across generations, it can be seen that the use of Ukrainian is diminishing with each generation. This shows that loss of language has taken place already in an earlier generation. When comparing loss of language across generations, it can be seen that $80 \%$ of the grandparents of the students in Tallinn used the Russian language when communicating with their grandchildren.

In case of all three cities it can be seen that loss of language has taken place already in the previous generation or the emigration has taken place from the Russian speaking regions of Ukraine and Belarus.

\section{Conclusion}

This study allows us to move from the familiar picture of a society with two dominant language groups to a deeper view of the unnoticed ethnic groups and languages and to monitor their development. Generally, as can be seen, the birth country does not determine the language used; the language is chosen on the basis of several other factors.

The size of the language group is not specifically the dimension of vitality of a language; the important factors are also the status of the language, the effect of mixed marriages on the language choice, etc. In case of small language groups, the determining factor is the attitude of the people speaking their native languages toward these languages. Overall, though, there is still a dominating trend of assimilating minority languages into Russian.

At the same time, the variations within a language group cannot be left unnoticed either - some of the minority nationalities are valuing their ethnic origins more and more and are trying to give their 
knowledge to their children as well, thus caring for the continuity and vitality of their language. The state institutions and the order of language teaching should take this into account as well.

\section{Address:}

Elvira Küün

Baltistikos katedra

Vilniaus universitetas

Universiteto g. 5

LT-01513 Vilnius

Lietuva

E-mail: elvira22@tlu.ee

\section{References}

Anderson, R. (2004) "First language loss in Spanish-speaking children: patterns of loss and implications for clinical practice". In B. Goldstein, ed. Bilingual language development and disorders in Spanish-English speakers, 187-212. Baltimore: Brookes.

Baker, C. (2006) Foundations of bilingual education and bilingualism. 4th ed. Clevedon: Multilingual Matters.

Baker, C. and S. P. Jones (1998) Encyclopedia of bilingualism and bilingual education. Clevedon: Multilingual Matters.

Bayley, R. and S. R. Schecter (2003) Language socialization in bilingual and multilingual societies. Clevedon: Multilingual Matters.

Commission of the European Communities (2005) Communication from the Commission to the Council, the European Parliament, the Economic and Social Committee and the Committee of the Regions. A new framework strategy for multilingualism. COM(2005)596 final. Available from <http://ec.europa.eu/education/policies/lang/doc/com596_en.pdf>. (cited 18.08.2009).

Crystal, D. (2000) Language death. Cambridge: Cambridge University Press.

Cummins, J. (1984) Bilingualism and special education: issues in assessment and pedagogy. Clevedon, England: Multilingual Matters.

Edwards, V. (2002) The other languages: a guide to multilingual classrooms. University of Reading: Reading and Language Information Centre.

Eesti Statistikaameti rahvaloendus 2000. [Estonian Statistics Executive Office's census 2000.] <http://www.stat.ee//gatekeeper.stat.ee:8000/px-web.2001/ Database/Rahvaloendus_regionaalne/Rahvaloendus_regionaalne.asp> (cited 18.08.2009). 


\section{Elvira Küün}

Extra, G. and Yagmur, K., ed. (2004) Urban multilingualism in Europe: immigrant minority languages at home and school. Clevedon: Multilingual Matters.

Gans, H.J. (1997) “Toward a reconciliation of 'assimilation' and 'pluralism': the interplay of acculturation and ethnic retention". International Migration Review 31, 4, 875-892.

Goldenberg, C., R. S. Rueda, and D. August (2006) "Sociocultural influences on the literacy development". In D. August and T. Shanahan, eds. Developing literacy in second-language learners. Report of the National Literacy Panel on Language-Minority Children and Youth. Washington, DC: Center for Applied Linguistic.

Hoffmann, C. and J. Ytsma, eds. (2004) "Trilingualism in family, school, and community”. In Language arts and disciplines, 43. (Bilingual Education and Bilingualism.) Clevedon: Multilingual Matters

Hyltenstam, K. and C. Stroud (1996) "Language maintenance”. In H. Goebl, P.H. Nelde, Z. Stary, and W. Wölk, eds. Contact linguistics: an international handbook of contemporary research. Berlin: Water de Gruyter.

Iskanius, S. (2005) Venäjänkielisten maahanmuuttajaopiskelijoiden kieliidentiteetti. [Russian-speaking immigrant students' linguistic identity.] Jyväskylä: University of Jyväskylä.

Kohnert, K., D. Yim, K. Nett, P. F. Kan, and L. Duran (2005) "Intervention with linguistically diverse preschool children: a focus on developing home language(s)". Language, Speech and Hearing Services in Schools 36, $3,251-263$.

Küün, E. (2008) “Kohtla-Järve ja Tallinna õpilaste kodukeel”. [Home language of school-children in Tallinn and Kohtla-Järve.] Haridus (Tallinn) 9-10, 2529.

Li, P. S. (2001) "The economics of minority language identity". Canadian Ethnic Studies 33, 3, 134-154.

McAdams, D. P. (1997). "The case for unity in the (post)modern self: a modest proposal". In R. D. Ashmore and L. Jussim, eds. Self and identity, 106136. Oxford: Oxford University Press.

Mills, J. (2001) "Being bilingual: perspectives of third generation Asian children on language culture and identity". International Journal of Bilingual Education and Bilingualism 4, 6, 383-402.

Monzó, L. and R. Rueda (2001) Constructing achievement orientations toward literacy: an analysis of sociocultural activity in Latino home and community contexts (CIERA Report No. 1-011). Ann Arbor, MI: Center for the Improvement of Early Reading Achievement.

Moon, B., M. Ben-Peretz, S. and Brown (2000) Routledge companion to education. London and New York: Routledge. 
Muldma, M. ed. (2009) Dialogue of cultures - possibility or inevitability? II. / Kultuuride dialoog - võimalus või paratamatus? II. Tallinn: Tallinn University Press.

Maardu linna ametlik lehekülg. [Official homepage of Maardu.] <http:// www.maardu.ee/index.php?page=65and $>$ (cited 18.08.2009).

Piller, I. (2002) Bilingual couples talk: the discursive construction of hybridity. Amsterdam: John Benjamins.

Rannut, M., Ü. Rannut, and A. Verschik (2003) Keel, võim, ühiskond. [Language, power, society.] Tallinn: Tallinn Pedagogical University Press.

Rannut, Ü. and Rannut, M. (2007) “Tallinna õpilaste kodukeel”. [Home language of pupils in Tallinn.] In Haridus (Tallinn) 3-4, 7-10.

Schwartz, M. (2008) "Exploring the relationship between family language policy and heritage language knowledge among second generation Russian-Jewish immigrants in Israel". Journal of Multilingual and Multicultural Development 29, 5, 400-418. <http://ejournals.ebsco.com/direct.asp? ArticleID=4D83A16ACC626DDA851D > (cited 18.08.2009).

Skutnabb-Kangas, T. (2000) Linguistic genocide in education - or worldwide diversity and human rights? Mahwah, NJ: Lawrence Erlbaum Associates.

Wong Fillmore, L. (1991). "When learning a second language means losing the first”. Early Childhood Research Quarterly 6, 323-346.

Kokkuvõte. Elvira Küün: Vähemuskeeled Eesti eralduvas keelekeskkonnas. Selle projekti eesmärk oli kindlaks määrata, milline on põhikooli teise kuni viienda klassi õpilaste kodune keel Eesti pealinnas Tallinnas. Samal ajal viidi uurimus läbi ka muudes Eesti regioonides: Kohtla-Järvel ja Maardus. 2000. aasta rahvaloenduse andmete (Eesti Statistikaamet 2000) järgi elab Eestis 142 etnilist rühma ning kokku räägitakse Eestis 109 erinevat keelt. Samal ajal ei nähtu andmebaasist, milliseid keeli kodus räägitakse. Antud artikli materjal kuulub uurimisteema "Põhikooliõpilaste kodune keel Tallinnas" (2007-2008) alla, mida rahastas ning mille tellis Eesti Haridus- ja Teadusministeerium (grant ETF 7065) rahvusvahelise uurimuse "Mitmekeelne projekt" jaoks. Uurimuses tehti kindlaks, milline keel domineerib igapäevases kasutuses, millised faktorid mõjutavad suhtluskeele valikut, millised on eelistatud keeled ja keeleoskus. Uurimus peegeldab keelesituatsiooni tegelikke suundi uuritud linnades.

Märksõnad: keele domineerimine, keele eluvõime, keeleoskus, keelrepertuaar, keelevalik, vähemuskeeled 
